\title{
Climate Dynamics, Invader Fitness, and Ecosystem Resistance in an Invasion-Factor Framework
}

\author{
Stephen L. Young, David R. Clements, and Antonio DiTommaso*
}

\begin{abstract}
As researchers and land managers increasingly seek to understand plant invasions and the external (climate) and internal (plant genetics) conditions that govern the process, new insight is helping to answer the elusive question of what makes some invasions successful and others not. Plant invasion success or failure is based on a combination of evolutionary and ecological processes. Abiotic (e.g., climate) and biotic (e.g., plant competition) conditions in the environment and plant genetics (e.g., fitness) combine in either decreasing or increasing invasion, yet it has proven challenging to know exactly which of these conditions leads to success for a given species, even when a wealth of empirical data is available. Further, current regional distribution models for invasive plant species rarely consider biotic and fitness interactions, instead focusing primarily on abiotic conditions. The crucial role of all three factors (climate dynamics, invader fitness, and ecosystem resistance) must not be ignored. Here we construct a three-factor invasion framework from which we develop conceptual models using empirical studies for yellow starthistle, nonnative common reed, and musk thistle, three dissimilar but commonly occurring invasive plant species in North America. We identify how components of the invasion process-rapid population increase, established local dominance, and rapid range expansion-are influenced by ecosystem resistance, invader fitness, and/or climate dynamics, a set of broadly defined factors for each of the three invasive plant species. Our framework can be used to (1) establish research priorities, (2) address gaps in theoretical understanding, and (3) identify invasion process components that can be targeted to improve management. Building on previous models, our unifying framework, which can be used for assessing any invasive plant species having sufficient empirical data, simultaneously shows the influence of ecosystem resistance, invader fitness, and climate dynamics factors on the invasion process.
\end{abstract}

Nomenclature: Common reed, Phragmites australis (Cav.) Trin. ex Steud.; musk thistle, Carduus nutans L.; yellow starthistle, Centaurea solstitialis $\mathrm{L}$.

Key words: Climate change, ecology, evolution, invasion theory, plasticity, predictive models.

Invasion Frameworks. Predicting outcomes and theorizing potential effects from invasions have long been key objectives of invasion research. Increasingly, invasion frameworks are being developed for many purposes, such as bringing consensus on terminology and improving clarity in proposed research (Colautti and MacIsaac 2004) or creating unifying classification systems (e.g., environmental impact) that use existing databases (Blackburn et al. 2014). Kolar

\footnotetext{
DOI: $10.1017 /$ inp.2017.28

* First and third authors: Adjunct Professor and Professor, Soil and Crop Sciences Section, School of Integrative Plant Science, Cornell University, Ithaca, NY 14853; second author: Professor, Department of Biology, Trinity Western University, Langley, BC V2Y 1Y1, Canada. Corresponding author’s E-mail: sly27@cornell.edu
}

and Lodge (2001) describe the invasion pathway from transport to introduction to establishment and identify points of failure along the way. They place their framework in predictive theory, suggesting scenarios and characteristics that may lead to the establishment of invasive species. Others have used traits (Alpert et al. 2000), conditions (Bradley et al. 2010), or a combination (Diez et al. 2012) as a base for their predictions about plant invasions.

Gurevitch et al. (2011) describe the invasion process, which begins after an introduction event has occurred, as rapid population increase, established local dominance, and rapid range expansion. These three components characterize invasions and often overlap in occurrence. For the relatively small contingent of invasive plants that actually become established, (e.g., roughly $10 \%$, as suggested by Williamson 1999), the invasion process would include an exponential 
increase in individuals (rapid population increase), the establishment of monotypic stands with limited or no diversity (established local dominance), and dispersal from population(s) occurring in transition/disturbance-mediated areas affected by, for example humans, animals, wind, or water (rapid range expansion).

Invasion Factors. Factors that affect the invasion process arise from the many ecological theories that have been proposed to explain the success of invasive plant species in new communities (Catford et al. 2009). Among these, one of the most common is the empty niche hypothesis, which proposes that successful establishment of invasive plant species is related to their ability to more effectively capture resources than resident native species (Hierro et al. 2005). In essence, empty niches, categorized as potentially unexploited resources (e.g., water, light, and nutrients), increase the likelihood of invasion in natural communities. The greater the number of empty niches available in a community, the greater the chance the community will be invaded (Davis et al. 2000; Hobbs and Huenneke 1992).

Empty niche theory, by itself, does not provide the reason for why nonnative plant species establish in novel habitats (Prieur-Richard and Lavorel 2000). Invasions can also occur by direct competition, when resources are not available to the invader. In this instance, the invader outcompetes native plants regardless of niche availability. At this point, it is important to distinguish between resource niche and species fitness (MacDougall et al. 2009). Chesson (2000) suggests these differences can have opposite effects on the outcome of competition. Niche differences are unilaterally applied to competing species, including native and invasive types, and result in limitations to both species and their general coexistence. Rare species often occur in areas with niche differences (Adler et al. 2007). Alternatively, fitness differences are purely competitive, with one species being favored over another through an inherent ability to access and acquire resources, both spatially and temporally. This dynamic relationship between competing species can lead to the demise of one and dominance of the other. In terms of fitness differences, species traits allow for a competitive advantage by one species over another, regardless of how common or rare they are (Mitchell and Power 2003).

Competition for resources depends both on the characteristics of the invader and the attributes of the native community (Blicker et al. 2002; Catford et al. 2009), which are not always mutually exclusive, as noted by "Darwin's naturalization hypothesis" (Thuiller et al. 2010). For the invader, leaf size, root distribution, and plant height are important for obtaining water, nutrients, and light. Further, the strategies of some invasive plants to successfully establish in new habitats include rapid growth, small or large seed size, and prolific seed production (Sutherland 2004). Plasticity is an important trait for invasive plants, as it allows one or a few introduced genotypes to acclimate in new and competitive habitats (Sultan 2003). In addition, invasive plant plasticity may evolve in response to new selection pressures (e.g., extreme drought events) during introductions into a range of habitat types (Chun 2011; Hierro et al. 2005). The invader and invaded community are subject to the effects of weather, including climate change, the effects of which constitute a significant knowledge gap in community ecology (Jentsch and Beierkuhnlein 2008). In temperate climates, episodes of heavy rainfall, summer flooding, and severe droughts are predicted (Intergovernmental Panel on Climate Change 2007; Zedler 2010) along with a concomitant increase in impacts from invasive plants, partly due to their more widespread distribution (Clements and DiTommaso 2011). Certainly, the effects of increased extreme weather patterns on facilitating or limiting plant invasions have not been studied extensively (Bradley et al. 2010).

Several framework models have been developed to combine various factors in the invasion process, and a comparison of these reveals that a productive conceptual approach has been to devise a three-factor framework (Table 1). The factors, which vary in focus among frameworks, can be broadly defined as biotic, abiotic, and intrinsic invader characteristics. Specific framework factors depend on the area(s) of emphasis (e.g., conceptual, theoretical, empirical, predictive) and availability of supporting research. In our framework, the role of climate change in facilitating invasion is a particular focus, so climate dynamics is a separate abiotic factor. The local abiotic and biotic factors with subcategories of macro- and microfauna, plant species composition, available nutrients, and soil type in our framework constitute ecosystem resistance to invasion. We used the term "ecosystem resistance" because of the inextricable linkage between living and nonliving soil components and the importance of other community influences. We provide a simultaneous conceptualization of the influence of climate dynamics, ecosystem resistance, and invader fitness (our intrinsic invader characteristic factor) on each component of the invasion process, which is the main difference between our approach and others (Table 1; Figure 1). With regard to climate, it is incorporated into "abiotic characteristics" in Catford et al. (2009), "environmental conditions" in Perkins et al. (2011), and "ecosystem processes" in Gurevitch et al. (2011), but these are much wider applications than our climate dynamics factor (Table 1). "System context" in Foxcroft et al. (2011) is an even broader category, incorporating propagule pressure and vector efficiency, as well as global climate change.

Here we provide new insight related to invasion theory by identifying ecosystem resistance, invader fitness, and climate dynamics as three broadly defined factors governing the invasion process, aiming to understand the dynamic integration of these three factors. We create an invasion-factor

216 - Invasive Plant Science and Management 10, July-September 2017 
Table 1. Comparison of 3-fold framework models for plant invasions that use factors categorized as biotic, abiotic, and intrinsic invader characteristics with the specific focus of each factor described and examples noted.

\begin{tabular}{|c|c|c|c|}
\hline Framework authors & Abiotic factor & Biotic factor & Intrinsic factor \\
\hline Perkins et al. $2011^{\mathrm{a}}$ & $\begin{array}{l}\text { Environmental conditions } \\
\text { (resources, habitat suitability, } \\
\text { global environmental } \\
\text { change) }\end{array}$ & $\begin{array}{l}\text { Biotic conditions (diversity, enemies, } \\
\text { mutualists, changes in land use and } \\
\text { disturbance regime) }\end{array}$ & $\begin{array}{l}\text { Invader attributes (competitive } \\
\text { ability, novel weapons, evolution of } \\
\text { invasiveness, engineering, } \\
\text { introduction effort) }\end{array}$ \\
\hline Foxcroft et al. 2011 & $\begin{array}{l}\text { System context (connectivity, } \\
\text { pathways, propagule } \\
\text { pressure, colonization } \\
\text { pressure, vector efficacy, } \\
\text { global climate change, } \\
\text { residence time, human values } \\
\text { and perceptions) }\end{array}$ & $\begin{array}{l}\text { Habitat susceptibility (bioclimatic } \\
\text { availability, local vector presence, } \\
\text { predation/consumer pressure, } \\
\text { resource availability, heterogeneity) }\end{array}$ & $\begin{array}{l}\text { Species characteristics/traits } \\
\text { (propagule production, dispersal } \\
\text { mode, defenses, resource demand, } \\
\text { competitiveness, seed-banking, } \\
\text { seed size, maximum growth rate) }\end{array}$ \\
\hline Gurevitch et al. 2011 & $\begin{array}{l}\text { Ecosystem processes (abiotic/ } \\
\text { climate, landscape } \\
\text { characteristics) }\end{array}$ & $\begin{array}{l}\text { Population interactions (regional } \\
\text { native species pool, community } \\
\text { characteristics, human impacts) }\end{array}$ & $\begin{array}{l}\text { Invader demography (dispersal } \\
\text { processes, organism traits, } \\
\text { evolutionary change) }\end{array}$ \\
\hline Present study & $\begin{array}{l}\text { Climate dynamics (normal } \\
\text { conditions [30-yr average], } \\
\text { extreme high/low } \\
\text { precipitation and } \\
\text { temperature, duration, } \\
\text { atmospheric } \mathrm{CO}_{2} \text { ) }\end{array}$ & $\begin{array}{l}\text { Ecosystem resistance (plant species, } \\
\text { soil type, nutrients, micro/macro- } \\
\text { fauna) }\end{array}$ & $\begin{array}{l}\text { Invader fitness (plant plasticity, } \\
\text { genetic mutation, phenological } \\
\text { adaptation, genetic selection) }\end{array}$ \\
\hline
\end{tabular}

${ }^{a}$ For Perkins et al. (2011), the last example in each factor is an "external influence," which we have assigned to factors of best fit.

framework (Figure 1) and then, using empirical studies published in the literature for three example invasive plant species, we develop conceptual models reflecting the current state of knowledge for each component of the invasion process. Our invasion-factor framework is a simple approach in determining the reason(s) for the success of individual invasive plant species. In addition, knowledge gaps can be identified where empirical studies would refute or support existing predictive models.

We combine bottom-up and top-down approaches in our invasion-factor framework by accounting for specific subcategories within factors and assessing information at a systems level. Our approach builds on frameworks developed by Catford et al. (2009), Gurevitch et al. (2011), and Perkins et al. (2011) by taking existing knowledge from published empirical research and portraying it graphically to show what is known and unknown about a component in the invasion process for any particular plant species. By creating a framework that provides a visual snapshot of a target invasive plant based on empirical studies, we provide a guide that can be used to (1) establish research priorities and
(2) identify components in the invasion process that can be targeted for successful management.

\section{Creation of an Invasion-Factor Framework for Ecosystem Resistance, Invader Fitness, and Climate Dynamics}

Studies were selected based on a search of the Web of Knowledge (v. 5.10) that aimed to identify ecosystem resistance, invader fitness, and climate dynamics as factors for which empirical studies have been conducted for three example invasive plant species. We chose yellow starthistle (Centaurea solstitialis L.), musk thistle (Carduus nutans L.), and nonnative common reed [Phragmites australis (Cav.) Trin. ex Steud.], which are well known for infesting rangelands, wildlands, and riparian areas, respectively (Carlson et al. 2009; Herrick and Wolf 2005; Meyerson et al. 2010; Whyte et al. 2008). The widespread occurrence of these three invasive plants ensured the highest likelihood of finding available peer-reviewed empirical research that 


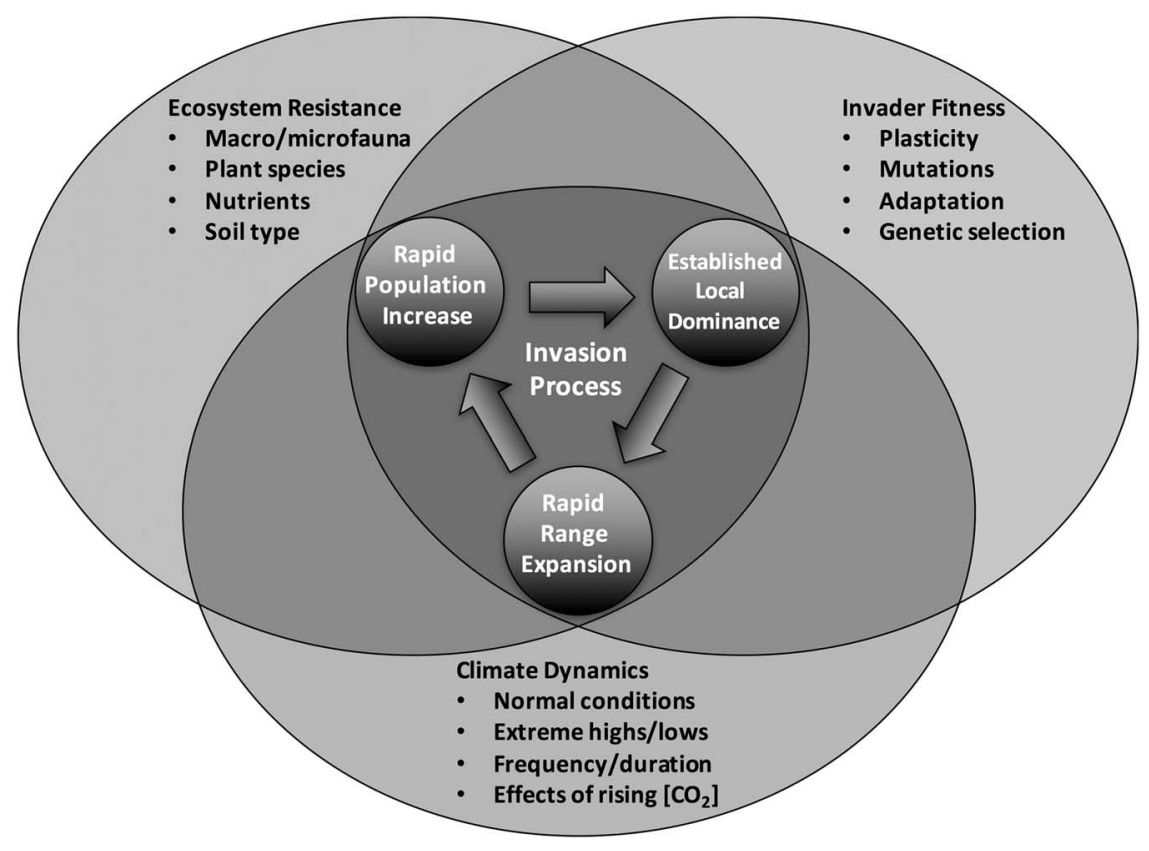

Figure 1. The invasion-factor framework of ecosystem resistance, invader fitness, and climate dynamics interacting to influence the invasion process. Where all three factors (i.e., circles) overlap, rapid population increase, established local dominance, and rapid range expansion occur unimpeded. Successful invasion fluctuates, as the strength and extent of influence from each factor can vary. A single subcategory or multiple subcategories under each factor may alter the invasion process and lower invasion success. The circles also illustrate situations in which one or two factors might limit invasion. Both the strength of the factors and the extent of their influence can change in space and time. Depending on the conditions, a factor such as extreme drought may alter any of the steps in the invasion process.

spanned the three factors with enough detail for building the conceptual models. Moreover, differences among the three species and in habitats they typically invade provided varying responses to the factors affecting the invasion process.

The following search terms were used: [("yellow starthistle" OR "Centaurea solstitialis"), ("musk thistle" OR "Carduus nutans"), ("invasive common reed" OR "nonnative common reed" OR "Phragmites australis")] AND [(resident OR "resident community" OR genetics OR "plant fitness" OR "phenotypic adaptation" OR mutation OR weather OR "climate change" OR "extreme event" OR precipitation OR temperature)]. The search was restricted to published articles, which did not include conference proceedings, reviews, or books (last date of search: August 1, 2016). For each reference, only empirical studies were retained for inclusion in the categorization process, of which 9, 14, and 19 were for yellow starthistle, musk thistle, and nonnative common reed, respectively, on at least one subcategory of an invasion factor (Tables 2-4). The main focus of each study was assigned to one of the four subcategories. Several studies had multiple subcategories. Studies were qualified as not affecting (0) or contributing to $(+)$ each of the three components of the invasion process-rapid population increase (PI), established local dominance (LD), and rapid range expansion (RE). The following describes the subcategories that were used for the three factors:

- Ecosystem Resistance. The four subcategories selected were macro- and microfauna, plant species composition, available nutrients, and soil type. These form the basis for the main biological and physical context of resident plant communities (Tilman 1988, 1999). Each of these subcategories either passively or actively shapes the plant community. Many previous frameworks have distinctly focused on abiotic versus biotic factors. The concept of ecosystem resistance (D'Antonio et al. 2001), including both abiotic and biotic features of a recipient environment, acknowledges that both factors interact dynamically to drive the invasion outcome, yet empirical studies can hardly separate each factor into independent effects (Kraft et al. 2015). For example, in sagebrush communities where once a keystone native species is reduced or removed [sagebrush (Artemisia spp.) itself], biotic resistance to invasion is reduced both through lack of competition and alteration of soil structure due to the change in community composition (Chambers et al. 2014; Prevéy et al. 2010). Animals and insects above- and belowground contribute to the dynamics of plant 
communities. The life histories of plant species contribute to the functional diversity of plant communities (Tilman et al. 1997). Smith-Ramesh et al. (2017) demonstrated that the entire food web is a better predictor of biotic resistance than interactions among a select group of competitors. Likewise, the soil context is a key component of ecosystem resistance. Macro- and micronutrients are spatially distributed throughout soils with uptake dependent on season, microbial community, and chemical bonding to minerals. The ranges in soil characterization can be from coarse sand to heavy clay, characterizations that relate to nutrient and water-holding capacity along with plant stability and resistance to disturbance.

- Invader Fitness. The four subcategories selected were plant plasticity, genetic mutation, phenological adaptation, and genetic selection. In the case of fitness, genetically superior plants that have mutated successfully are able to resist deleterious action(s) or condition(s) through growth, development, and phenology (Vila-Aiub et al.
2015). The phenotypic traits displayed are an expression of those genes in a surviving plant. The traits are modifications that may or may not adapt to continued selection pressure(s).

- Climate Dynamics. The four subcategories selected were normal conditions (30-yr averages), extreme high/low precipitation and temperature, duration of extremes, and rising atmospheric $\mathrm{CO}_{2}$ concentrations. Extremes in weather affect plants. Over the past decade, the increasingly large fluctuation from long-term average conditions has resulted in extremely high and low temperature and precipitation levels. During a normal year, drought or flooding may still negatively impact plants because of altered frequency and duration of precipitation. Increasing $\mathrm{CO}_{2}$ concentrations in the atmosphere are having a positive effect on the growth of certain plants (e.g., $\mathrm{C}_{3}$ plants), which could provide nonnative plants with an advantage in the invasion process (Bradley et al. 2010; Diez et al. 2012; Ziska 2010).

Table 2. Empirical studies addressing ecosystem resistance, invader fitness, and climate dynamics of the invasion process for yellow starthistle.

\begin{tabular}{|c|c|c|c|c|c|}
\hline \multirow[b]{2}{*}{ Factor } & \multirow[b]{2}{*}{ Subcategory $^{a}$} & \multirow[b]{2}{*}{ Main focus } & \multicolumn{3}{|c|}{ Invasion process ${ }^{\mathrm{b}}$} \\
\hline & & & PI & LD & $\mathrm{RE}$ \\
\hline \multicolumn{6}{|l|}{ Ecosystem resistance } \\
\hline Young et al. 2009 & $\begin{array}{l}\text { Fauna } \\
\text { Species }\end{array}$ & $\begin{array}{l}\text { Herbivore activity: simulated grazing } \\
\text { Annual or perennial forbs and grasses }\end{array}$ & + & 0 & 0 \\
\hline Brown and Rice 2010 & $\begin{array}{l}\text { Species } \\
\text { Nutrients }\end{array}$ & $\begin{array}{l}\text { Annual or perennial forbs and grasses } \\
\text { Fertility: high and low }\end{array}$ & + & 0 & 0 \\
\hline Young et al. 2010 & $\begin{array}{l}\text { Species } \\
\text { Soil type }\end{array}$ & $\begin{array}{l}\text { Yellow starthistle, perennial grasses, and forbs } \\
\text { Water availability }\end{array}$ & + & + & 0 \\
\hline Young et al. 2011 & $\begin{array}{l}\text { Fauna } \\
\text { Species } \\
\text { Soil type }\end{array}$ & $\begin{array}{l}\text { Herbivore activity: simulated grazing } \\
\text { Annual/perennial forbs, grasses, and mixes } \\
\text { Water availability }\end{array}$ & + & + & 0 \\
\hline \multicolumn{6}{|l|}{ Invader fitness } \\
\hline Sterling et al. 2001 & $\begin{array}{l}\text { Plasticity } \\
\text { Selection }\end{array}$ & $\begin{array}{l}\text { Growth: resource competition } \\
\text { Resistance to herbicides }\end{array}$ & + & 0 & 0 \\
\hline Swope and Parker 2010 & Phenology & Timing/mechanism: flowering/biocontrol & + & 0 & 0 \\
\hline Dlugosch et al. 2015 & $\begin{array}{l}\text { Plasticity } \\
\text { Phenology }\end{array}$ & $\begin{array}{l}\text { Growth: plant and seed biomass } \\
\text { Timing: germination, flowering }\end{array}$ & + & + & 0 \\
\hline \multicolumn{6}{|l|}{ Climate dynamics } \\
\hline Roché et al. 1997 & $\begin{array}{l}\text { Normal } \\
\text { Duration }\end{array}$ & $\begin{array}{l}\text { Native range: } 2 \text { to } 38 \mathrm{C} \text { seed germination } \\
\text { Length of field and seed germination studies }\end{array}$ & + & + & + \\
\hline Hierro et al. 2009 & $\begin{array}{l}\text { Normal } \\
\text { Extreme }\end{array}$ & $\begin{array}{l}\text { Native range: Mediterranean region } \\
\text { Precipitation: Dry and wet summers }\end{array}$ & + & + & + \\
\hline
\end{tabular}

a The main focus of each study is briefly described in one or more subcategories that make up a factor. Subcategories are macro/ microfauna (fauna), plant species (species), nutrients, and soil type for ecosystem resistance, plasticity, genetic mutations (mutation), phenological adaptation (phenology), and genetic selection (selection) for invader fitness, and normal conditions (normal), extreme highs and lows (extreme), duration, and $\mathrm{CO}_{2}$ for climate dynamics. Studies may not have addressed every subcategory for each factor.

b Studies were qualified as not affecting (0) or contributing to $(+)$ each of the three components of the invasion process: rapid population increase (PI), established local dominance (LD), and rapid range expansion (RE). 
Table 3. Empirical studies addressing the resident community, invader fitness, and weather factors of the invasion process for musk thistle.

\begin{tabular}{|c|c|c|c|c|c|}
\hline \multirow[b]{2}{*}{$\underline{\text { Factor }}$} & \multirow[b]{2}{*}{ Subcategory ${ }^{a}$} & \multirow[b]{2}{*}{ Main focus } & \multicolumn{3}{|c|}{ Invasion process ${ }^{\mathrm{b}}$} \\
\hline & & & PI & $\mathrm{LD}$ & RE \\
\hline \multicolumn{6}{|l|}{ Ecosystem resistance } \\
\hline Rauschert and Shea 2012 & $\begin{array}{l}\text { Fauna } \\
\text { Species }\end{array}$ & $\begin{array}{l}\text { Herbivore activity: simulated grazing } \\
\text { Pasture grasses in old fields }\end{array}$ & 0 & + & 0 \\
\hline Adkins and Barnes 2013 & Species & Established perennial grasses & 0 & + & 0 \\
\hline Han and Young 2014a & $\begin{array}{l}\text { Fauna } \\
\text { Species }\end{array}$ & $\begin{array}{l}\text { Herbivore activity: simulated grazing } \\
\text { Cool- and warm-season perennial grasses }\end{array}$ & 0 & + & 0 \\
\hline \multicolumn{5}{|l|}{ Invader fitness } & 0 \\
\hline Jongejans et al. 2006 & Plasticity & Growth: plant and seed biomass & + & 0 & + \\
\hline Skarpaas et al. 2011 & $\begin{array}{l}\text { Plasticity } \\
\text { Phenology }\end{array}$ & $\begin{array}{l}\text { Growth: seed biomass } \\
\text { Timing: germination }\end{array}$ & + & 0 & + \\
\hline Zhang et al. 2011a & Plasticity & Growth: height; reproduction: seed survival & + & 0 & + \\
\hline Han and Young 2013 & $\begin{array}{l}\text { Plasticity } \\
\text { Phenology }\end{array}$ & $\begin{array}{l}\text { Reproduction: seed longevity } \\
\text { Timing: germination }\end{array}$ & + & 0 & 0 \\
\hline Han and Young 2014b & $\begin{array}{l}\text { Plasticity } \\
\text { Phenology }\end{array}$ & $\begin{array}{l}\text { Growth: root elongation } \\
\text { Timing: native perennial grasses }\end{array}$ & + & 0 & 0 \\
\hline \multicolumn{6}{|l|}{ Climate dynamics } \\
\hline Zhang et al. $2011 \mathrm{~b}$ & $\begin{array}{l}\text { Normal } \\
\text { Extreme } \\
\text { Duration }\end{array}$ & $\begin{array}{l}\text { Native range: Rock Springs, PA } \\
+0.58 \mathrm{C} \text { daily; }+15-30 \% \text { annual precipitation } \\
\text { Length of field study }\end{array}$ & 0 & 0 & + \\
\hline Marchetto et al. 2012 & $\begin{array}{l}\text { Normal } \\
\text { Extreme } \\
\text { Duration }\end{array}$ & $\begin{array}{l}\text { Native range: Duncannon, PA } \\
\text { Drying treatments: } 10,23 \text {, or } 28 \mathrm{C} \\
\text { Length of laboratory study }\end{array}$ & 0 & 0 & + \\
\hline Zhang et al. 2012a & $\begin{array}{l}\text { Normal } \\
\text { Extreme } \\
\text { Duration }\end{array}$ & $\begin{array}{l}\text { Native range: Rock Springs, PA } \\
\text { Day/night: } 15 / 15 \text { C, } 20 / 15 \text { C, } 25 / 15 \text { C } \\
\text { Length of field and greenhouse studies }\end{array}$ & 0 & + & 0 \\
\hline Zhang et al. 2012b, 2012c & $\begin{array}{l}\text { Normal } \\
\text { Extreme } \\
\text { Duration }\end{array}$ & $\begin{array}{l}\text { Native range: Rock Springs, PA } \\
\text { Temperature: }+0.58 \text { C daily soil surface } \\
\text { Length of field study }\end{array}$ & 0 & + & + \\
\hline Han and Young 2016 & $\begin{array}{l}\text { Normal } \\
\text { Extreme } \\
\text { Duration }\end{array}$ & $\begin{array}{l}\text { Native range: North Platte, NE } \\
\text { Precipitation: normal; } 33 \% \text { of average } \\
\text { Second year of field study }\end{array}$ & + & 0 & + \\
\hline
\end{tabular}

${ }^{a}$ The main focus of each study is briefly described in one or more subcategory that makes up a factor. Subcategories are macro/micro fauna (fauna), plant species (species), nutrients, and soil type for resident community factor, plasticity, genetic mutations (mutation), phenological adaptation (phenology), and genetic selection (selection) for invader fitness factor, and normal conditions (normal), extreme highs and lows (extreme), duration, and $\mathrm{CO}_{2}$ for weather factor. Studies may not have addressed every subcategory for each factor.

b Studies were qualified as not affecting (0) or contributing to $(+)$ each of the three components of the invasion process: rapid population increase (PI), established local dominance (LD), and rapid range expansion (RE).

\section{Invasion-Factor Framework: Categorization for Three Species}

Yellow Starthistle. Yellow starthistle is an annual forb native to Eurasia and thought to have been first introduced into the United States through Chilean-grown alfalfa (Medicago sativa L.) in the 1850s (DiTomaso et al. 2006).
This species now covers over 6 million ha in California and can be found in most western states, spreading as far east as New York state. Yellow starthistle is found in Canada from British Columbia to Ontario, primarily in the southernmost regions and in nearly all Mediterranean climates and most temperate areas of the world (DiTomaso et al. 2006). 
Table 4. Empirical studies addressing the resident community, invader fitness, and weather factors of the invasion process for nonnative common reed.

\begin{tabular}{|c|c|c|c|c|c|}
\hline \multirow[b]{2}{*}{ Factor } & \multirow[b]{2}{*}{ Subcategory $^{\mathrm{a}}$} & \multirow[b]{2}{*}{ Main focus } & \multicolumn{3}{|c|}{ Invasion process ${ }^{b}$} \\
\hline & & & PI & LD & RE \\
\hline \multicolumn{6}{|l|}{ Ecosystem resistance } \\
\hline Byun et al. 2013 & Species & Competition with other plants & + & + & 0 \\
\hline Chambers et al. 1999 & $\begin{array}{l}\text { Fauna } \\
\text { Nutrients } \\
\text { Soil type }\end{array}$ & $\begin{array}{l}\text { Reduction of native biodiversity } \\
\text { High nutrient environments } \\
\text { Alteration of hydrology }\end{array}$ & + & + & 0 \\
\hline Allen et al. 2015 & Fauna & Lipara gall flies for biocontrol & + & 0 & 0 \\
\hline Crocker et al. 2015 & Fauna & Microorganisms to defend against Pythium & + & + & 0 \\
\hline Hazelton et al. 2015 & Fauna & Herbivore activity in stands of various ages & 0 & + & 0 \\
\hline Song et al. 2015 & $\begin{array}{l}\text { Fauna } \\
\text { Species } \\
\text { Nutrients } \\
\text { Soil type }\end{array}$ & $\begin{array}{l}\text { Microbial diversity } \\
\text { Displacement of native Scirpus planiculmis } \\
\text { High nitrogen environments } \\
\text { Organic matter in invaded communities }\end{array}$ & + & + & 0 \\
\hline Tripathee and Shäfer 2015 & Species & Belowground biomass: native and nonnative & + & + & 0 \\
\hline Alldred et al. 2016 & $\begin{array}{l}\text { Species } \\
\text { Nutrients }\end{array}$ & $\begin{array}{l}\text { Established aquatic dominant Typha latifolia } \\
\text { High nitrogen environments }\end{array}$ & + & + & 0 \\
\hline \multicolumn{6}{|l|}{ Invader fitness } \\
\hline McCormick et al. 2010 & Selection & Unique, genetically distinct patches & 0 & + & 0 \\
\hline Albert et al. 2015 & Selection & Diverse genotypes in roadside populations & 0 & 0 & + \\
\hline Jeon et al. 2015 & $\begin{array}{l}\text { Plasticity } \\
\text { Phenology }\end{array}$ & $\begin{array}{l}\text { Three distinct genetic profiles based on age } \\
\text { Growth adjusted based on environment }\end{array}$ & + & 0 & 0 \\
\hline Nada et al. 2015 & $\begin{array}{l}\text { Plasticity } \\
\text { Selection }\end{array}$ & $\begin{array}{l}\text { Stress-inducible genes adjust for salinity } \\
\text { Ecotypes evolve to different environments }\end{array}$ & 0 & 0 & + \\
\hline Wu et al. 2015 & Selection & Native and nonnative hybridizing & 0 & 0 & + \\
\hline Engloner and Szegö 2016 & Selection & Clone diversity across wetland topography & 0 & + & 0 \\
\hline \multicolumn{6}{|l|}{ Climate dynamics } \\
\hline Carlson-Mazur et al. 2014 & $\begin{array}{l}\text { Normal } \\
\text { Extreme }\end{array}$ & $\begin{array}{l}\text { Cool wet winters } \\
\text { Drier, milder winters, fluctuating water levels }\end{array}$ & 0 & + & + \\
\hline Caplan et al. 2015 & $\begin{array}{l}\text { Normal } \\
\mathrm{CO}_{2}\end{array}$ & $\begin{array}{l}\text { Ambient } \mathrm{CO}_{2} \text { levels } \\
\text { Enhanced } \mathrm{CO}_{2} \text { and nitrogen effects biomass }\end{array}$ & + & 0 & + \\
\hline Kim et al. 2015 & $\begin{array}{l}\text { Normal } \\
\text { Extreme } \\
\text { Duration } \\
\mathrm{CO}_{2}\end{array}$ & $\begin{array}{l}\text { Monsoonal weather } \\
\text { Rising sea level with climate change } \\
\text { Long-term change in monsoon conditions } \\
+300 \text { ppm } \mathrm{CO}_{2}\end{array}$ & + & 0 & + \\
\hline Lee and An 2015 & $\begin{array}{l}\text { Normal } \\
\text { Extreme } \\
\text { Duration }\end{array}$ & $\begin{array}{l}\text { Intertidal flooding } \\
\text { Reduced flooding and salinity } \\
\text { Long-term pattern }\end{array}$ & + & 0 & 0 \\
\hline Tougas-Tellier et al. 2015 & $\begin{array}{l}\text { Normal } \\
\text { Extreme } \\
\text { Duration }\end{array}$ & $\begin{array}{l}\text { Stable water levels } \\
\text { Significant fluctuation in water levels } \\
\text { Long-term pattern }\end{array}$ & + & + & + \\
\hline Mamat et al. 2016 & $\begin{array}{l}\text { Extreme } \\
\text { Duration }\end{array}$ & $\begin{array}{l}\text { Low soil moisture levels } \\
\text { Fluctuations in water levels near desert oasis }\end{array}$ & + & 0 & 0 \\
\hline
\end{tabular}

${ }^{a}$ The main focus of each study is briefly described in one or more subcategory that makes up a factor. Subcategories are macro/ microfauna (fauna), plant species (species), nutrients, and soil type for resident community factor, plasticity, genetic mutations (mutation), phenological adaptation (phenology), and genetic selection (selection) for invader fitness factor, and normal conditions (normal), extreme highs and lows (extreme), duration, and $\mathrm{CO}_{2}$ for weather factor. Studies may not have addressed every subcategory for each factor.

${ }^{\mathrm{b}}$ Studies were qualified as not affecting (0) or contributing to $(+)$ each of the three components of the invasion process: rapid population increase (PI), established local dominance (LD), and rapid range expansion (RE). 
To date, the most extensive empirical studies relating to the ecosystem resistance factor for yellow starthistle are from California, where it first became well established, leading to its dominance and range expansion. For long-term $(>5 \mathrm{yr})$ research studies, Brown and Rice (2010) and Young et al. (2009) established plant communities ranging from individual to multiple species of annual and perennial forbs and grasses (Table 2). Further, each species was selected based on the length of time required to achieve maturity, from early to late season, with multiple combinations of maturity timings. Species were also selected based on their ability to fix atmospheric nitrogen in high- and low-fertility soils. Young et al. (2010, 2011) conducted more detailed studies on root growth patterns and light availability and soil moisture as mechanisms by which yellow starthistle outcompetes native plants during invasion into established communities.

Based on these studies, the ecosystem resistance factor influenced all components of the invasion process for yellow starthistle, except for rapid range expansion (Table 2). Functionally similar plant communities are most effective in preventing rapid population increases, because reproduction in yellow starthistle is reduced or averted in these communities (see Daehler 2001). Annual introduced grass and native forb communities were ineffective in limiting invasion by yellow starthistle. The rapid population increase component of the yellow starthistle invasion process was likely most affected by ecosystem resistance.

The genetics of yellow starthistle relative to invader fitness has not received much research attention. Resistance to herbicides by yellow starthistle requires selection of genes that can metabolize a control chemical and is largely a defense mechanism for survival (Sterling et al. 2001). Similarly, accessing or storing resources that are spatiotemporally limited depends on the plasticity and adaptive capacity (i.e., phenology) of a plant. Genetic mutations that result in greater fitness (larger size) are the result of the differences between environments of the yellow starthistle native and invaded habitat (Dlugosch et al. 2015). Fitness can also be compromised by multiple constraints resulting from phenological adaptations (Swope and Parker 2010).

The fitness of yellow starthistle will influence the invasion process based primarily on how quickly a population is able to increase (Table 2). Plant genetic diversity or lack thereof is a known bottleneck in ecological and evolutionary processes, including invasion. Developing resistance or increasing fitness is dependent on both genetic diversity and intensity of the selection pressure. Although relatively few, the studies reviewed provide supporting evidence of a high level of fitness in yellow starthistle in relation to the invasion process that may explain the widespread colonization of this species in much of the western United States. Only recently has climate dynamics, especially extreme drought, become a factor of greater interest and influence on the invasion process.
Empirical research assessing the impact of climate on yellow starthistle invasions has been performed in the western United States. The overlap of climate dynamics with the two previous factors (i.e., ecosystem resistance and invader fitness) is highly possible, because conditions such as persistent drought can alter plant communities and act as a selection pressure affecting fitness. The comparison of growth and development of an invader in its home range compared with its invaded range can reveal important characteristics, even germination propensity (Hierro et al. 2009). More extensive research that involves the manipulation of variables, such as planting dates and planting densities in the invaded range, can reveal the effects of weather-related conditions of temperature and photoperiod on yellow starthistle (Roché et al. 1997).

Changes in climate can profoundly influence the invasion process for yellow starthistle (Table 2). Seed germination in this species is highly temperature and moisture dependent regardless of planting density, photoperiod, and vernalization. As weather extremes become more common, it is likely that ecosystem resistance will be more closely linked to invader fitness factors that influence the invasion process of yellow starthistle. In some regions, drought will inhibit yellow starthistle invasion completely, while new regions with increasing precipitation may become (more) vulnerable to this invader.

Based on available information (Table 2), it is clear that all three factors in the framework: ecosystem resistance, invader fitness, and climate dynamics can act to spur on the rapid population increase component of the invasion process for yellow starthistle. Thus, the three factors could conceivably work synergistically to promote rapid population increase. Likewise, the established local dominance component is fairly consistently promoted by all three factors under conditions favoring the invader. However, it is interesting that the rapid range expansion component is only observed under the influence of climate extremes. This is an indication of how critical it is to monitor or predict yellow starthistle range expansion under climate change conditions such as increased precipitation, increased temperature, or modified drought cycles, which favor expansion (Hierro et al. 2009; Roché et al. 1997) at the edges of its present range.

Musk Thistle. A monocarpic herb, musk thistle was first introduced into the United States from Europe, North Africa, and Asia in the late 1800s (Moore and Frankton 1974). Its life cycle varies and it can be a summer or winter annual, biennial, or short-lived perennial (Zhang and Shea 2012). Plants develop a deep root system over an 8- to 10 -mo period and produce large quantities of seeds that are easily dispersed by wind (Silva et al. 2014). Widespread in North America, musk thistle continues to establish large monotypic stands that displace native plants and forage 
species for livestock and wildlife (Rauschert et al. 2015; Silva et al. 2014).

Much basic and applied research exists on the biology and ecology of musk thistle in relation to the invasion process. As an invasive plant that thrives in niches created by disturbances (Zhang and Shea 2012), musk thistle has been extensively studied as a competitor in plant communities (Table 3). Seed is the primary mechanism sustaining musk thistle invasions, and the presence of natural predators introduced in the invaded range may be limiting rapid range expansion (Marchetto et al. 2014). The resilience of musk thistle to compete for resources and exhibit a high level of plasticity in response to climate (Young 2015) is as important as its ability to produce copious amounts of seed in invaded areas even in the presence of biological control agents. The high degree of adaptability of musk thistle to variations in the environment could be a key feature of its invasiveness.

In the midwestern United States, Han and Young (2014a) report that musk thistle can outcompete perennial grasses, especially where niches are created either artificially (e.g., grazing) or naturally (e.g., extreme drought). The species is opportunistic and can readily adapt in habitats denuded of vegetation (Adkins and Barnes 2013) or where some vegetation is present (Rauschert et al. 2015). Niches in plant communities, such as openings in the plant canopy, allow musk thistle to establish; without them, it is nearly impossible for this species to be present (Rauschert and Shea 2012). The effect of microsite disturbance characteristics (e.g., type, size, and water availability) on musk thistle establishment was examined in an old-field habitat in eastern Pennsylvania (Rauschert and Shea 2012). The size of musk thistle plants most influenced local dominance. Rauschert et al. (2015) conducted extensive studies on disturbance type, size of musk thistle, and frequency and timing of musk thistle growth. Further, Rauschert and Shea (2012) and Zhang and Shea (2012) showed how inter- and intraspecific competition between musk thistle and related plumeless thistle (Carduus acanthoides L.) at several spatial scales contributes to a multiple-aspect disturbance framework relating to management.

Plasticity in musk thistle growth is a key feature of its invasion success. Several studies have documented morphological and physiological adaptations in vegetative and reproductive structures in musk thistle (Table 3). For example, in its native European range, musk thistle is less tolerant of natural enemies and experiences severe seed losses that limit population growth (Jongejans et al. 2006). Specific seed traits have been studied to better understand the trade-off between seed size (larger $=$ higher germination) and seed dispersal distance (smaller $=$ farther travel) with environment (wind) strongly influencing dispersal and ultimately its establishment in new regions (Skarpaas et al. 2011). The seed mass-dispersal-establishment paradox in musk thistle is dependent on species traits and environmental conditions (Han and Young 2013). For example, early-dispersing seeds have lower germination than seeds that remain on the parent plant for up to 9 to $12 \mathrm{wk}$ after the capitula matures; an indication of a possible fitness advantage among select individuals.

Musk thistle can tolerate intense disturbances (mowing); however, no seeds are typically produced, as the removal of the shoot apex disrupts apical dominance (Zhang et al. 2011a). In another monocarpic species, marsh yellowcress [Rorippa palustris (L.) Bess.], the effect of disturbance intensity on root sprouting was evaluated as a measure of fitness (Sosnová et al. 2014). Sosnová et al. (2014) found that high phenotypic plasticity in life histories, as opposed to root sprouting, was more likely to occur under conditions of unpredictable, severe disturbance. Musk thistle is also monocarpic and not known to have root sprouts, but Han and Young (2014b) report that its shallow roots may facilitate invasion into warm-season grasslands, where resident grasses have fewer roots distributed in the upper soil profile. Belowground plasticity in musk thistle appears to be similar to responses aboveground, especially under abiotic extremes (e.g., drought). This species can access niche resources by quickly altering its phenology; a feature that in time could be considered a fitness advantage that facilitates establishment (Han and Young 2016).

Weather events associated with climate change have affected musk thistle biology and ecology (Table 3). Zhang et al. (2012a) measured seed germination and seedling emergence of musk thistle and found both to occur more quickly when parent plants were grown under warmer conditions relative to controls. Similarly, Zhang et al. (2012c) reported that musk thistle plants grown under warmer conditions were taller, thus contributing to more rapid range expansion by having its seeds more widely dispersed. Warmer conditions also affect the morphology of this species through a negative correlation between temperature and density of prickles on leaves, possibly making them more palatable to large herbivores (Zhang et al. $2012 \mathrm{~b}$ ). The dispersal ability of musk thistle is affected positively (larger growth) and negatively (higher precipitation lowers seed production) by climate change (Zhang et al. 2011b). Marchetto et al. (2012) suggested that musk thistle seed released during hot, dry conditions may increase plant invader fitness, potentially by increasing dispersal distances.

In the context of climate, musk thistle has been studied mainly to better understand climate effects on the seed mass-dispersal-establishment paradox. Few studies have directly addressed extreme weather events and invasion success of musk thistle at the systems level. In the midwestern United States, musk thistle establishes in warmand cool-season perennial grasslands when a niche is created (e.g., by overgrazing), yet Han and Young (2016) found this was not the case during extreme drought. Light availability 
and early-season moisture were adequate in the slowly wilting grass-dominated canopy, which may have caused musk thistle plants to bolt, but eventually all plants of the invader died without producing a single inflorescence (Young 2015). In this case, the invasion process for musk thistle was brought to a halt due to extreme drought, suggesting that plasticity is not always beneficial when conditions change abruptly.

Among the three major factors in the framework, the invasion components are sharply differentiated between ecosystem resistance and invader fitness (Table 3). Whereas invader fitness influences the rapid population increase component, established local dominance depends on the invaded community being favorable. Thus, for an invaded population of musk thistle to go through all three invasion components, the model suggests that even if a particular factor favors invasion (e.g., climate change), whether the population can become locally dominant also depends on ecosystem resistance, and whether rapid population increase occurs depends on conditions favoring local adaptation (invader fitness factor). Although this assessment of how the three factors interrelate is based on relatively few studies, it is clear that in comparison to yellow starthistle, there tend to be more barriers to invasion for musk thistle (see Table 2).

Nonnative Common Reed. Nonnative common reed reproduces sexually from seed and vegetatively from stolons and rhizomes. Local spread of nonnative common reed is predominantly through vegetative growth and regeneration, while establishment of new populations occurs through dispersal of seeds, rhizomes, and sod fragments (Gucker 2008). Extensive rhizome and stolon growth produces dense nonnative common reed stands. Rhizomes of the introduced lineage are thick, "deep seated," and scaly and can grow to 20-m lengths and to depths greater than $1 \mathrm{~m}$ (Holm et al. 1977).

The success of nonnative common reed as an ecologically dominant species is evident from its ability to displace constituents of native wetland plant communities, such as common cattail (Typha latifolia L.) or panicled bulrush (Scirpus microcarpus J. Presl \& C. Presl) (Alldred et al. 2016; Byun et al. 2013; Song et al. 2015; Table 4). Byun et al. (2013) tested biotic resistance of plant communities and found that among four different functional types, fast-growing annuals displayed the highest biotic resistance but also that communities with a high diversity of functional types could provide even more biotic resistance to invasion by nonnative common reed. Still, in many of their experiments involving 36 different wetland species, nonnative common reed was the dominant competitor (Byun et al. 2013). Furthermore, nonnative common reed tends to have relatively few natural enemies, such as pathogens or herbivorous insects, in invaded environments (Allen et al. 2015; Crocker et al. 2015; Table 4). Like other clonal wetland species, nonnative common reed can quickly become the dominant community constituent under favorable conditions. Native communities are vulnerable to new incursions of nonnative common reed, as has been observed in North America and other regions (Alldred et al. 2016; Song et al. 2015), unless they are able to produce biotic resistance through preempting niches as they become available, which may be the case for fast-growing annuals (Byun et al. 2013)

From both genetic and ecological studies, it is clear that the recent range expansion of nonnative common reed in North America has resulted from a combination of the introduction of multiple Eurasian genotypes (Chambers et al. 1999; Meyerson and Cronin 2013; Saltonstall 2002) and various human-induced changes in wetland environments (Bertness et al. 2002; Burdick and Konisky 2003; Chambers et al. 2008; King et al. 2007). Until recently, a single lineage was thought to be responsible for the European form but with at least one additional European haplotype (Meyerson and Cronin 2013); genetic change could result in further spread of nonnative common reed than previously thought possible (Carlson-Mazur et al. 2014). Unlike many clonal species, range expansion of nonnative common reed is frequently due to reproduction from seed, a mode that promotes genetic diversity within populations (Carlson-Mazur et al. 2014; McCormick et al. 2010; Meyerson and Cronin 2013) and increases the potential to invade new niches. As a result, many areas infested by nonnative common reed exhibit a surprisingly high level of genetic diversity (Table 4). In a given area, there may be patches reproducing clonally, but the patches tend to be differentiated and are generally thought to arise from seed (Albert et al. 2015; Engloner and Szegö 2016; McCormick et al. 2010). Furthermore, there is evidence of hybridization with native biotypes (Wu et al. 2015) and plasticity via stress-inducible genotypes that tolerate varying salinity levels found in different environments (Nada et al. 2015).

Likely, the most important response to evaluate in nonnative common reed in light of climate dynamics is its response to wider fluctuations in water levels that are predicted under climate change (Table 4). Seed production in nonnative common reed may be promoted by periodic reductions in water levels, providing opportunities for germination of seeds on temporarily exposed substrates (Carlson-Mazur et al. 2014; Lee and An 2015; TougasTellier et al. 2015; Table 4). Extreme flooding could also increase the invasiveness of nonnative common reed by disrupting existing vegetation and depth profiles and by directly spreading its propagules (Kim et al. 2015).

Climate change will tend to have less immediate impact on nonnative common reed expansion than land-use changes. Genetic changes combined with climate change are predicted to expand the area suitable for nonnative common reed, such as the Great Lakes region of 
North America with an expected increase in drier, milder winters (Carlson-Mazur et al. 2014). Although nonnative common reed has been largely confined to eastern Canada, Catling and Mitrow (2011) predicted a potentially large expansion of its range by 2030 , with this plant colonizing southern prairie regions and parts of British Columbia based on current plant hardiness zones; these authors anticipated an even greater expansion if climate change is taken into account. Furthermore, increases in atmospheric $\mathrm{CO}_{2}$ concentrations have been experimentally shown to increase nonnative common reed's biomass at a much higher rate than for many other plant species, especially in conjunction with increased eutrophication, which could also result from climate change (Caplan et al. 2015).

As for whether nonnative common reed establishes local dominance, much depends on the ecosystem resistance factor (Table 4). However, extremes in climate, particularly changes in flooding regimes, interact with the ecosystem resistance factor by reducing dominance of other wetland plant species (Carlson-Mazur et al. 2014; Tougas-Tellier et al. 2015). The third major factor, fitness, can influence how different genotypes of nonnative common reed may arise during the invasion process (Engloner and Szegö 2016; Jeon et al. 2015). Interactions among the three factors in the framework indicate that as habitats change, either through climate change or other anthropogenic manipulations, nonnative common reed is capable of invading by establishing local dominance in areas where other plant species formerly existed.

\section{Using the Invasion-Factor Framework to Measure Success}

Following categorization, the results of each study were analyzed qualitatively to determine whether the factor contributed to $(+)$ or had no effect on (0) PI (rapid population increase), LD (established local dominance), and/or RE (rapid range expansion) (Tables 2-4). Conceptual models were created for the three example invasive plant species by plotting the number of studies indicating the likelihood of success in one or more component of the invasion process (Figure 2).

Not surprisingly, there was no single paper that addressed every subcategory of a factor, as the volume of information would have likely been too extensive to cover in one study. Even for factors that were described by researchers, a subcategory may still not have been covered or adequately addressed, in which case we used our research experience and knowledge of the example invasive species. Conceptual models are based on available data or knowledge at the time and therefore can be quite fluid. It is expected that many iterations of these models may be constructed over time, incorporating new information as it becomes available.
Some of the more recent conceptual models depicting invasions have broadly synthesized concepts and theory to test hypotheses, improved understanding, and identified research directions (Catford et al. 2009; Gurevitch et al. 2011; Kueffer et al. 2013) or have taken a reductionist approach by focusing on fluctuating resource availability (Davis et al. 2000), the invader and biotic resistance (Facon et al. 2006), introduced and native ranges (van Kleunen et al. 2010), and current and future climate conditions (Ibáńez et al. 2014). Our approach builds on several of these frameworks (e.g., Catford et al. 2009; Gurevitch et al. 2011; Perkins et al. 2011), as we take existing knowledge from published empirical studies and portray it graphically to show what is known and unknown about a component in the invasion process for any particular plant species.

Ecosystem Resistance. Niche theory and the evolution of increased competitive ability (EICA) hypothesis help to explain ecosystem resistance effects on our three example invasive plant species. A resident community with spatial or temporal gaps and an inability to outcompete an invader released from its natural enemies (Joshi et al. 2014) is more likely to experience one or more of the components of the invasion process. Rapid range expansion was the component least likely to limit invasion success for our three example invasive plant species (Figure 2a), a fact supported by the current distribution patterns of these three species in North America. However, musk thistle, a prolific seed producer, is limited in establishing local dominance by the resident community, while yellow starthistle, which also reproduces only by seed, is most limited by its inability to rapidly increase in population size (Figure 2a). Ecosystem resistance limits nonnative common reed invasion by preventing rapid population increases and local dominance. The differences between these components could be due to life histories, but also scale. Among individual plants, competition for resources occurs within a narrow range, thus exerting greater influence on invasion success at a small scale.

We recommend studies that address interactions between specific invasive plant species and target functionally different communities across a range of scales. This approach is likely to provide valuable information on ecosystem resistance so as to better demonstrate effects on the three components of the invasion process. For example, this could be achieved by collecting data on leaf size, root distribution, and plant height at local to regional scales using controlled environmental and field studies. The response of plant reproductive features (e.g., seed size and number) to competition in resident communities would also provide information on potential plant species and mixtures used in restoration, an important component for management.

Invader Fitness. Phenotypic plasticity and genetic adaption play a role in plant invasion success. Over a period of 

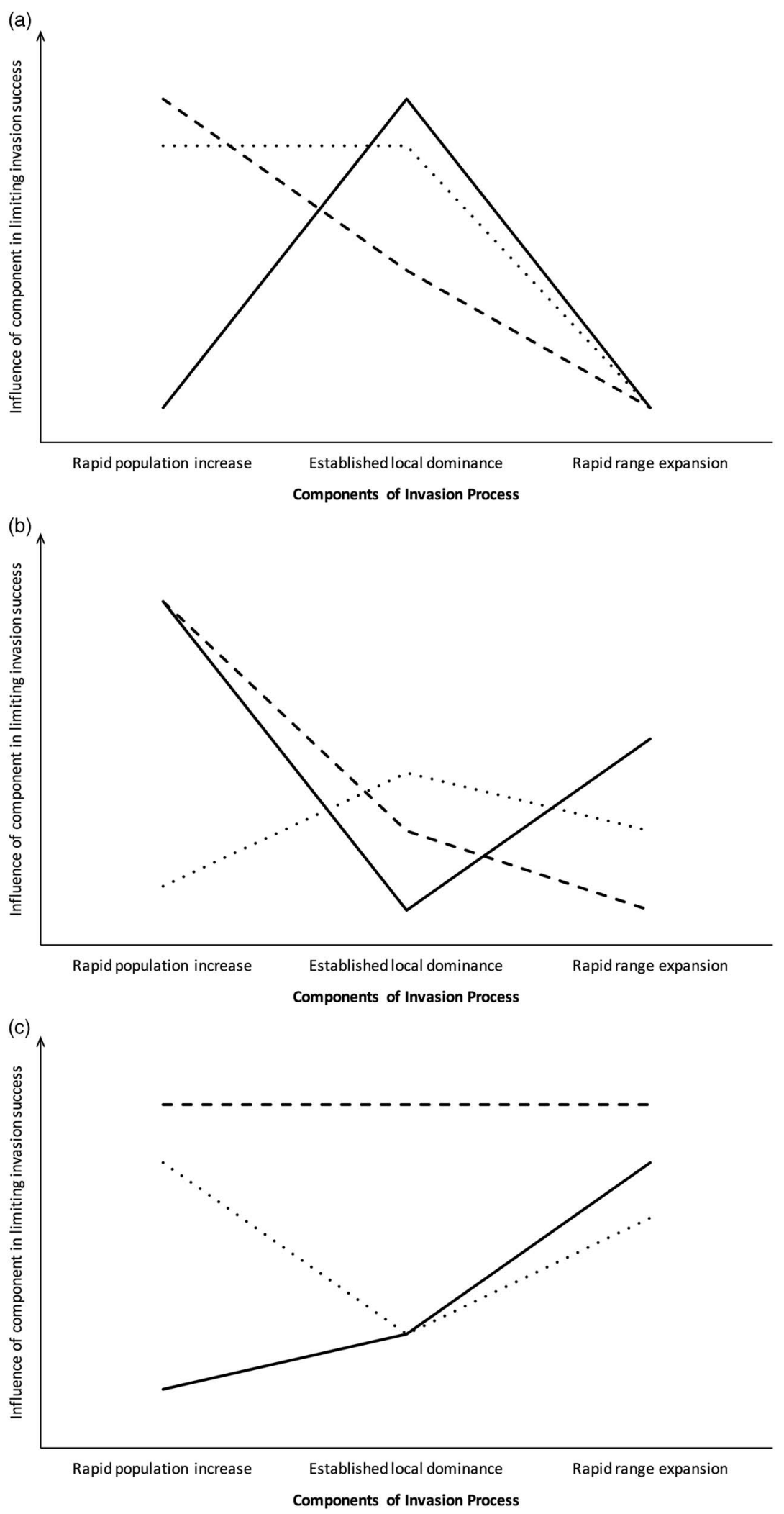
time, plant interactions with the environment may result in populations or individuals with higher fitness. Interestingly, fitness of the three example invasive plant species appears to be inhibited by a different factor in each case, that is, least influenced by rapid population increase for nonnative common reed, established local dominance for musk thistle, and rapid range expansion for yellow starthistle (Figure 2b). These differences are striking and seemingly consistent with the EICA hypothesis. Ellstrand and Schierenbeck (2000) suggest that the native habitat actually constrains some invasive plants, while the new habitat acts as a selection pressure for others. Perhaps the minimal influence of rapid population increase in limiting successful invasion by nonnative common reed is due to the species being released from the constraints of the native habitat, while the new habitat is exerting greater selection pressure and limiting invasion success in establishing local dominance (Figure 2b). Similarly, musk thistle and yellow starthistle have yet to achieve a fitness advantage to rapidly increase populations because of the constraints of the new habitat. What remains unknown is the intensity and duration of selection pressures needed to drive local ecotype creation and life history alterations among invasive plant species. Further, very little is known about the components of the invasion process and what may limit the success of yet to be introduced plants that are "born into" or "made" by their new habitat.

We suggest greater use of common garden studies comparing invasive plants collected from different regions and imposing selection pressures that can potentially prove to be very useful for assessing fitness advantages. Another approach would be to use long-term data sets (e.g., LTER sites) to determine population changes over decadal timescales. Old fields with historical data and herbaria with genetic records are potential sources of data to determine genetic adaptations by invasive plant species.

Climate Dynamics. Extremes in climate are predicted to continue well into the future. The impact of these changes on invasive plants could be either beneficial through increasing atmospheric $\mathrm{CO}_{2}$ concentrations that stimulate plant growth and development (Ziska 2003) or detrimental by direct and nonselective effects (e.g., drought) (Skelton et al. 2015). Chambers et al. (2014) report several factors, including rising $\mathrm{CO}_{2}$ concentrations, that have contributed to the expanded range of downy brome (Bromus tectorum $\mathrm{L}$.) in the Great Basin of the United States. For our three example invasive plant species, climate (precipitation and temperature) limits invasion success primarily by affecting the rapid range expansion component (Figure 2c). However, current predictive models suggest otherwise. For example, Bradley et al. (2009) identify summer and spring precipitation and winter and spring minimum temperatures constraining yellow starthistle and predict climate change will lead to more widespread distribution of this species in the western United States. Ibánez et al. (2014), who identified three components of range expansion (dispersal, colonization, and proliferation), conclude that for the perennial vine oriental bittersweet (Celastrus orbiculatus Thunb.), colonization in New England could increase significantly under warmer and drier conditions. The discrepancies between empirical studies, which our conceptual model is based on, and predictive models have yet to be reconciled, highlighting an area where collaboration is needed.

We believe that climate needs to be considered one of the most important factors to address via species-specific empirical studies within the context of invasion success. The lack of agreement between empirically based conceptual models and data-driven projection models (e.g., bioclimatic envelope models) is an area for much needed research. For example, studies on specific invasive plant responses to extreme climate events in North American grasslands would provide insight on whether invasive plant species exhibit a biogeographical pattern of abundant center - the point at which the physiological fitness of the invader is maximized. Further, would a combination of biotic and abiotic constraints result in a skewing of the abundance niche relative to the establishment niche of invasive species along climatic gradients? A combination of greenhouse and field studies along with climate probability models would explain, in this case, the possibility of higher intensities of competition in less stressful environments.

Factor Integration. The three factors in our framework: ecosystem resistance, invader fitness, and climate dynamics may be integrated in multiple ways. In general, longestablished resident communities are less vulnerable to invasion than disturbed communities (Hobbes and Huenneke 1992), and climate change, particularly climate extremes, can make communities more vulnerable to invasion, as seen in changes in rainfall regimes that favor rapid population growth of yellow starthistle (Hierro et al. 2009) or changes in flooding regimes that promote establishment and local dominance of nonnative common reed

Figure 2. Theoretical invasion process for three commonly occurring invasive plants and the effect from ecosystem resistance (a), invader fitness (b), and climate dynamics (c) according to published studies (Tables 1-3). The invasive plants musk thistle, nonnative common reed, and yellow starthistle are represented by a solid line, a dotted line, and a dashed line, respectively. Process 1 (a): ecosystem resistance is reported to have the greatest effect for all three invaders during the component of established local dominance. Process 2 (b): phenotypic adaptation is reported to be the most limiting during the rapid population increase component for musk thistle and yellow starthistle. Process 3 (c): climate dynamics are reported to limit the rapid range expansion component for all three invaders. 
(Carlson-Mazur et al. 2014; Tougas-Tellier et al. 2015). Climate change may in turn create new selection pressures to increase fitness of invading populations (Clements and DiTommaso 2011). The clear synergism among ecosystem resistance, invader fitness, and climate dynamics as factors influencing invasion makes a case for assessing all three factors simultaneously to better understand the invasion process (Tables 2-4).

Summary. We have categorized empirical studies on musk thistle, yellow starthistle, and nonnative common reed into ecosystem resistance, invader fitness, and climate dynamics to increase our understanding of the invasion processes of these three widespread invasive plant species. We have identified research needs in one or more of the invasion process components-rapid population increase, established local dominance, and rapid range expansion - for each of the three invasive plant species. Our theoretical invasion process model, which builds on previous three-factor frameworks (Catford et al. 2009; Gurevitch et al. 2011; Perkins et al. 2011), demonstrates that any one of the three factors composed of four subcategories, and others that we may not have identified, can limit successful invasion. In some instances, a knowledge gap may exist due to an absence of studies (e.g., atmospheric $\mathrm{CO}_{2}$ concentration as a climate factor for the three example invasive plant species), while additional research may be needed for finer geographic variations overlooked at coarser scales. We believe that none of the three factors can be neglected or studied in isolation and more integrated research is needed, such as Young (2015), who documented that invasion failure by musk thistle was due to a lack of plasticity (invader fitness) in a native perennial grassland (ecosystem resistance) during extreme drought (climate dynamics). These types of empirical studies can be used as examples for developing invasion-factor framework models beyond what we have presented here in providing a visual invasive plant snapshot that can guide research and the implementation of successful management strategies.

\section{Acknowledgments}

Extensive comments and suggestions provided by several anonymous reviewers substantially improved this article. Partial funding was provided by the U.S. Department of Agriculture, National Institute of Food and Agriculture (NIFA) under Agreement No. 2014-70006-22484 and through a NIFA-Hatch grant NYC-125439.

\section{Literature Cited}

Adkins JK, Barnes TG (2013) Herbicide treatment and timing for controlling Kentucky bluegrass (Poa pratensis) and tall fescue (Festuca arundinacea) in cool season grasslands of central Kentucky, USA. Nat Area J 33:31-38
Adler PB, HilleRisLambers J, Levine JM (2007) A niche for neutrality. Ecol Lett 10:95-104

Albert A, Brisson J, Belzile F, Turgeon J, Lavoie C (2015) Strategies for a successful plant invasion: the reproduction of Phragmites australis in north-eastern North America. J Ecol 103:1529-1537

Alldred M, Baines SB, Finlay S (2016) Effects of invasive-plant management on nitrogen-removal serves in freshwater tidal marshes. PLoS ONE 11:e0149813

Allen WJ, Young RE, Bhattarai GP, Croy JR, Lambert AM, Meyerson LA, Cronin JT (2015) Multitrophic enemy escape of invasive Phragmites australis and its introduced herbivores in North America. Biol Invasions 17:3419-3432

Alpert P, Bone E, Holzapfel C (2000) Invasiveness, invasibility and the role of environmental stress in the spread of non-native plants. Persp Plant Ecol Evol Syst 3:52-66

Bertness MD, Ewanchuk PJ, Silliman BR (2002) Anthropogenic modification of New England salt marsh landscapes. Proc Natl Acad Sci USA 99:1395-1398

Blackburn TM, Essl F, Evans T, Hulme PE, Jeschke JM, Kuhn I, Kumschick S, Markova Z, Mrugała A, Nentwig W, Perg J, Pysek P, Rabitsch W, Ricciardi A, Richardson DM, Sendek A, Vila M, Wilson JR, Winter M, Genovesi P, Bacher S (2014) A unified classification of alien species based on the magnitude of their environmental impacts. PLoS Biol 12:e1001850

Blicker PS, Olson BE, Engel R (2002) Traits of the invasive Centaurea maculosa and two native grasses: effect of N supply. Plant Soil 247:261-269

Bradley BA, Blumenthal DM, Wilcove DS, Ziska LH (2010) Predicting plant invasions in an era of global change. Trends Ecol Evol 25:310-318

Bradley BA, Oppenheimer MO, Wilcove DS (2009) Climate change and plant invasions: restoration opportunities ahead? Glob Change Biol 15:1511-1521

Brown CS, Rice KJ (2010) Effects of belowground research use complementarity on invasion of constructed grassland plant communities. Biol Invasions 12:1319-1334

Burdick DM, Konisky RA (2003) Determinants of expansion for Phragmites australis, common reed, in natural and impacted coastal marshes. Estuaries 26:407-416

Byun C, de Biois S, Brisson J (2013) Plant functional group identity and diversity determine biotic resistance to invasion by an exotic grass. J Ecol 101:128-139

Caplan JS, Hager RN, Megonigal JP, Mozdzer TJ (2015) Global change accelerates carbon assimilation by a wetland ecosystem engineer. Environ Res Lett 10:115006. http://iopscience.iop.org/1748-9326/10/11/115006. Accessed: September 2, 2016

Carlson ML, Kowalski KP, Wilcox DA (2009) Promoting species establishment in a Phragmites-dominated Great Lakes coastal wetland. Nat Area J 29:263-280

Carlson-Mazur ML, Kowalski KP, Galbraith D (2014) Assessment of suitable habitat for Phragmites australis (common reed) in the Great Lakes coastal zone. Aquatic Inv 9:1-19

Catford JA, Jansson R, Nilsson C (2009) Reducing redundancy in invasion ecology by integrating hypotheses into a single theoretical framework. Divers Distrib 15:22-40

Catling PM, Mitrow G (2011) The recent spread and potential distribution of Phragmites australis subsp. australis in Canada. Can Field Nat 125:95-104

Chambers JC, Bradley BA, Brown CS, D'Antonio C, Germino MJ, Grace JB, Hardegree SP, Miller RF, Pyke DA (2014) Resilience to 
stress and disturbance, and resistance to Bromus tectorum L. invasion in cold desert shrublands of Western North America. Ecosystems $17: 360-375$

Chambers RM, Havens KJ, Killeen S, Berman M (2008) Common reed Phragmites australis occurrence and adjacent land use along estuarine shoreline in Chesapeake Bay. Wetlands 28:1097-1103

Chambers RM, Meyerson LA, Saltonstall K (1999) Expansion of Phragmites australis into tidal wetlands of North America. Aquatic Bot 64:261-273

Chesson P (2000) Mechanisms of maintenance of species diversity. Ann Rev Ecol Syst 31:343-366

Chun YJ (2011) Phenotypic plasticity of introduced versus native purple loosestrife: univariate and multivariate reaction norm approaches. Biol Invasions 13:819-829

Clements DR, DiTommaso A (2011) Climate change and weed adaptation: can evolution of invasive plants lead to greater range expansion than forecasted? Weed Res 51:227-240

Colautti RI, MacIsaac HJ (2004) A neutral terminology to define "invasive" species. Div Dist 10:135-141

Crocker EV, Karp MA, Nelson EB (2015) Virulence of oomycete pathogens from Phragmites australis-invaded and noninvaded soils to seedlings of wetland plant species. Ecol Evol 5:2127-2139

Daehler CC (2001) Darwin's naturalization hypothesis revisited. Am Nat 158:324-330

D'Antonio C, Levine J, Thomsen M (2001) Ecosystem resistance to invasion and the role of propagule supply: a California perspective. J Mediterranean Ecol 2:233-246

Davis MA, Grime JP, Thompson K (2000) Fluctuating resources in plant communities: a general theory of invasibility. J Ecol 88 : 528-534

Diez JM, D’Antonio CM, Dukes JS, Grosholz ED, Olden JD, Sorte CB, Blumenthal DM, Bradley BA, Early R, Ibáńez I, Jones SJ, Lawler JJ, Miller LP (2012) Will extreme climatic events facilitate biological invasions? Front Ecol Environ 10:249-257

DiTomaso JM, Kyser GB, Pitcairn MJ (2006) Yellow Starthistle Management Guide. Berkeley, CA: California Invasive Plant Council Publication 2006-03. $78 \mathrm{p}$

Dlugosch KM, Cang FA, Barker BS, Andonian K, Swope SM, Rieseberg LH (2015) Evolution of invasiveness through increased resource use in a vacant niche. Nature Plants 1:15066

Ellstrand NC, Schierenbeck KA (2000) Hybridization as a stimulus for the evolution of invasiveness in plants? Proc Natl Acad Sci USA 97:7043-7050

Engloner AI, Szegö D (2016) Genetic diversity of riverine reed stands indicating the water regime of the habitat. Ecol Indic 61: 846-849

Facon B, Genton BJ, Shykoff J, Jarne P, Estoup A, David P (2006) A general eco-evolutionary framework for understanding bioinvasions. Trends Ecol Evol 21:130-135

Foxcroft LC, Pickett STA, Cadenasso ML (2011) Expanding the conceptual frameworks of plant invasion ecology. Persp Plant Ecol Evol Syst 13:89-100

Gucker CL (2008) Phragmites australis. United States Department of Agriculture Forest Service. http://www.fs.fed.us/database/feis/plants/ graminoid/phraus/all.html. Accessed: September 2, 2016

Gurevitch J, Fox GA, Wardle GM, Inderjit, Taub D (2011) Emergent insights from the synthesis of conceptual frameworks for biological invasions. Ecol Lett 14:407-418
Han C, Young SL (2013) Ecology of musk thistle (Carduus nutans) seed germination for grasslands of temperate climates. Weed Sci 61:549-556

Han C, Young SL (2014a) Drought and grazing disturbances and resistance to invasion by warm- and cool-season perennial grassland communities. Ecol Restor 32:28-36

Han C, Young SL (2014b) Root growth of two perennial grass types and musk thistle (Carduus nutans) in temperate grasslands of North America. Invasive Plant Sci Manag 7:387-397

Han C, Young SL (2016) Invasion during extreme weather: success and failure in a temperate perennial grassland. Great Plains Res 26:50-59

Hazelton EG, McCormick MK, Sievers M, Kettenring KM, Whigham DF (2015) Stand age is associated with clonal diversity, but not vigor, community structure, or insect herbivory in Chesapeake Bay Phragmites australis. Wetlands 35:877-888

Herrick BM, Wolf AT (2005) Invasive plant species in diked vs. undiked Great Lakes wetlands. J Great Lakes Res 31:277-287

Hierro JL, Eren O, Khetsuriani L, Diaconu A, Torok K, Montesinos D, Andonian K, Kikodze D, Janoian L, Villarreal D, Estanga-Mollica M, Callaway RM (2009) Germination responses of an invasive species in native and non-native ranges. Oikos 118:529-538

Hierro JL, Maron JL, Callaway RM (2005) A biogeographical approach to plant invasions: the importance of studying exotics in their introduced and native range. J Ecol 93:5-15

Hobbs RJ, Huenneke LF (1992) Disturbance, diversity, and invasion: implications for conservation. Conserv Biol 6:324-337

Holm LG, Plocknett DL, Pancho JV, Herberger JP (1977) The World's Worst Weeds: Distribution and Biology. Honolulu, HI: University of Hawai' i Press. 609 p

Ibáńez I, Diez JM, Miller LP, Olden JD, Sorte CB, Blumenthal DM, Bradley BA, D'Antonio CM, Dukes JS, Early RI, Grosholz ED, Lawler JJ (2014) Integrated assessment of biological invasions. Ecol Appl 24:25-37

[IPCC] Intergovernmental Panel on Climate Change (2007) Climate change 2007. Pages 848-926 in Solomon S, Qin D, Manning M, Chen Z, Marquis M, Averyt KB, Tignor M, Miller HL, eds. The Physical Science Basis. Contribution of Working Group I to the Fourth Assessment Report of the Intergovernmental Panel on Climate Change. New York: Cambridge University Press

Jentsch A, Beierkuhnlein CR (2008) Effects of extreme meteorological events on ecosystems. Geoscience 340:621-628

Jeon IS, Kwon DS, Shin H, Kim WB, Kang NR, Whang SM, Kim MS, Wi SJ, Park KY (2015) Effects of phenotypic and RAPD variations on ecophysiological characterization of reeds (Phragmites australis) in Suncheon Bay. J Plant Biol 58:175-182

Jongejans E, Sheppard AW, Shea K (2006) What controls the population dynamics of the invasive thistle Carduus nutans in its native range? J Appl Ecol 43:877-886

Joshi S, Gruntman M, Bilton M, Seifan M, Tielborger K (2014) A comprehensive test of evolutionarily increased competitive ability in a highly invasive plant species. Annals Bot 114:1761-1768

Kim JY, Kim GY, Do Y, Joo GJ (2015) Effects of monsoon on topography, soil variables, and coastal plants. Estuaries Coasts 38:494-505

King RS, Deluca WV, Whigham DF, Marra PP (2007) Threshold effects of coastal urbanization on Phragmites australis (common reed) abundance and foliar nitrogen in Chesapeake Bay. Estuaries Coasts 30:469-481

Kolar CS, Lodge DM (2001) Progress in invasion biology: predicting invaders. Trends Ecol Evol 16:199-204 
Kraft NJB, Adler PB, Godoy O, James EC, Fuller S, Levine JM (2015) Community assembly, coexistence and the environmental filtering metaphor. Funct Ecol 29:592-599

Kueffer C, Pyšek P, Richardson DM (2013) Integrative invasion science: model systems, multi-site studies, focused meta-analysis and invasion syndromes. New Phytol 200:615-633

Lee J, An S (2015) Effect of dikes on the distribution and characteristics of Phragmites australis in temperate intertidal wetlands located in the South Sea of Korea. Ocean Sci J 50:49-59

MacDougall AS, Gilbert B, Levine JM (2009) Plant invasions and the niche. J Ecol 97:609-615

Mamat Z, Halik U, Muhtar P, Nurmamat I, Abliz A, Aishan T (2016) Influence of soil moisture and electrical conductivity on the growth of Phragmites australis (Cav.) in the Keriya oasis, China. Environ Earth Sci 75:423

Marchetto KM, Jongejans E, Shea K, Auhl R (2012) Water loss from flower heads predicts seed release in two invasive thistles. Plant Ecol Divers 5:57-65

Marchetto KM, Shea K, Kelly D, Groenteman R, Sezen Z, Jongejans E (2014) Unrecognized impact of a biocontrol agent on the spread rate of an invasive thistle. Ecol Appl 24:1178-1187

McCormick MK, Kettenring KM, Baron HM, Whigham DF (2010) Extent and reproductive mechanisms of Phragmites australis spread in brackish wetlands in Chesapeake Bay, Maryland (USA). Wetlands 30:67-74

Meyerson LA, Cronin JT (2013) Evidence for multiple introductions of Phragmites australis to North America: detection of a new non-native haplotype. Biol Invasions 15:2605-2608

Meyerson LA, Viola DV, Brown RN (2010) Hybridization of invasive Phragmites australis with a native subspecies in North America. Biol Invasions 12:103-111

Mitchell CE, Power AG (2003) Release of invasive plants from fungal and viral pathogens. Nature 421:625-627

Moore RJ, Frankton C (1974) The thistles of Canada. Monograph No. 10. Ottawa: Canada Department of Agriculture. Pp 54-61

Nada RM, Khedr AHA, Serag MS, El-Nagar NA (2015) Growth, photosynthesis and stress-inducible genes of Phragmites australis (Cav.) Trin. ex Steudel from different habitats. Aquatic Bot 124:54-62

Perkins LB, Leger EA, Nowak RS (2011) Invasion triangle: an organizational framework for species invasion. Ecol Evol 1:610-625

Prevéy JS, Germino MJ, Huntly NJ, Inouye RS (2010) Exotic plants increase and native plant decrease with loss of foundation species in sagebrush steppe. Plant Ecol 207:39-51

Prieur-Richard A, Lavorel S (2000) Invasions: the perspective of diverse plant communities. Austral Ecol 25:1-7

Rauschert EJ, Shea K (2012) Influence of microsite disturbance on the establishment of two congeneric invasive thistles. PLoS ONE 7:e45490

Rauschert ES, Shea K, Goslee S (2015) Plant community associations of two invasive thistles. Ann Bot (Lond) 7:plv065

Roché CT, Thill DC, Shafii B (1997) Reproductive phenology in yellow starthistle (Centaurea solstitialis). Weed Sci 45:763-770

Saltonstall K (2002) Cryptic invasion by a non-native genotype of the common reed, Phragmites australis, into North America. Proc Natl Acad Sci USA 99:2445-2449

Silva FL, Donega MA, Cerdeira AL, Corniani N, Velini ED, Cantrell CL, Dayan FE, Coelho MN, Shea K, Duke SO (2014) Roots of the invasive species Carduus nutans L. and C. acanthoides L. produce large amounts of aplotaxene, a possible allelochemical. J Chem Ecol 40:276-284
Skarpaas O, Silverman EJ, Jongejans E, Shea K (2011) Are the best dispersers the best colonizers? Seed mass, dispersal and establishment in Carduus thistles. Evol Ecol 25:155-169

Skelton RP, West AG, Dawson TE (2015) Predicting plant vulnerability to drought in biodiverse regions using functional traits. Proc Natl Acad Sci USA 112:5744-5749

Smith-Ramesh LM, Moore AC, Schmitz OJ (2017) Global synthesis suggests that food web connectance correlates to invasion resistance. Glob Change Biol 23:465-473

Song K, Lee J, Cha C-J, Kang H (2015) Effects of Phragmites invasion on soil microbial activity and structure in a brackish marsh. Plant Soil 392:45-56

Sosnová M, Herben T, Martínková J, Bartušková A, Klimešová J (2014) To resprout or not to resprout? Modeling population dynamics of a root-sprouting monocarpic plant under various disturbance regimes. Plant Ecol 215:1245-1254

Sterling TM, Norman KL, Murray LW (2001) Picloram-resistant and -susceptible yellow starthistle accessions have similar competitive ability. Weed Sci 49:42-47

Sutherland S (2004) What makes a weed a weed: life history traits of native and exotic plants in the USA. Oecologia 141:24-39

Sultan SE (2003) Phenotypic plasticity in plants: a case study in ecological development. Evol Dev 5:25-33

Swope SM, Parker IM (2010) Trait-mediated interactions and lifetime fitness of the invasive plant Centaurea solstitialis. Ecology 91:2284-2293

Thuiller W, Gallien L, Boulangeat I, de Bello F, Munkemuller T, Roquet C, Lavergne S (2010) Resolving Darwin's naturalization conundrum: a quest for evidence. Divers Distrib 16:461-475

Tilman D (1988) Plant Strategies and the Dynamics and Structure of Plant Communities. Princeton, NJ: Princeton University Press. 385 p

Tilman D (1999) The ecological consequences of changes in biodiversity: a search for general principles. Ecology 80:1455-1474

Tilman D, Knops J, Wedin D, Reich P, Ritchie M, Siemann E (1997) The influence of functional diversity and composition on ecosystem processes. Science 277:1300-1302

Tougas-Tellier MA, Morin J, Hatin D, Lavoie C (2015) Freshwater wetlands: fertile grounds for the invasive Phragmites australis in a climate change context. Ecol Evol 5:3421-3435

Tripathee R, Schäfer VR (2015) Above- and belowground biomass allocation in four dominant salt marsh species of the Eastern United States. Wetlands 35:21-30

van Kleunen M, Weber E, Fischer M (2010) A meta-analysis of trait differences between invasive and non-invasive plant species. Ecol Lett 13:235-245

Vila-Aiub MM, Gundel PE, Preston C (2015) Experimental methods for estimation of plant fitness costs associated with herbicideresistance genes. Weed Sci 63:203-216

Whyte RS, Trexel-Kroll D, Klarer DM, Shields R, Francko DA (2008) The invasion and spread of Phragmites australis during a period of low water in a Lake Erie coastal wetland. J Coastal Res 55:111-120

Williamson M (1999) Can the impacts of invasive plants be predicted? Pages 11-19 in Proceedings of the 5th International Conference on Ecology of Invasive Alien Plants. Sardinia, Italy

Wu CA, Murray LA, Heffernan KE (2015) Evidence for natural hybridization between native and introduced lineages of Phragmites australis in the Chesapeake Bay watershed. Am J Bot 102:805-812

Young SL (2015) When an invasive plant fails to invade. Front Ecol Environ 13:450-451 
Young SL, Barney JN, Kyser GB, Jones TS, DiTomaso JM (2009) Functionally similar species confer greater resistance to invasion: implications for grassland restoration. Restor Ecol 17:884-892

Young SL, Kyser GB, Barney JN, Claassen VP, DiTomaso JM (2010) Spatio-temporal relationship between water depletion and root distribution patterns of Centaurea solstitialis and two native perennials. Restor Ecol 18:323-333

Young SL, Kyser GB, Barney JN, Claassen VP, DiTomaso JM (2011) The role of light and soil moisture in plant community resistance to invasion by yellow starthistle (Centaurea solstitialis). Restor Ecol 19:599-606

Zhang R, Gallagher RS, Shea K (2012a) Maternal warming affects early life stages of an invasive thistle. Plant Biol 14:783-788

Zhang R, Heberling JM, Haner E, Shea K (2011a) Tolerance of two invasive thistles to repeated disturbance. Ecol Res 26:575-581

Zhang R, Jongejans E, Shea K (2011b) Warming increases the spread of an invasive thistle. PLoS ONE 6:e21725

Zhang R, Leshak A, Shea K (2012b) Decreased structural defence of an invasive thistle under warming. Plant Biol 14:249-252
Zhang R, Post E, Shea K (2012c) Warming leads to divergent responses but similarly improved performance of two invasive thistles. Popul Ecol 54:583-589

Zhang R, Shea K (2012) Integrating multiple disturbance aspects: management of an invasive thistle, Carduus nutans. Ann Bot-London 110:1395-1401

Zedler JB (2010) How frequent storms affect wetland vegetation: a preview of climate-change impacts. Front Ecol Environ 8: 540-547

Ziska LH (2003) Evaluation of the growth response of six invasive species to past, present and future atmospheric carbon dioxide. J Exp Bot 54:395-404

Ziska LH (2010) Elevated carbon dioxide alters chemical management of Canada thistle in no-till soybean. Field Crops Res 119:299-303

Received September 5, 2016, and approved July 27, 2017.

Associate Editor for this paper: Guillaume Fried, ANSES. 